\title{
Standardization and Storage Study of Aonla (Emblica officinalis Gaertn) based Blended Ready-To-Serve Beverages
}

\author{
Naval Singh Devra, R.A. Kaushik and H.R. Meena* \\ ${ }^{1}$ Department of Horticulture, Rajasthan College of Agriculture, MPUAT, \\ Udaipur- 313001(Rajasthan), India \\ ${ }^{2}$ ICAR- Indian Institute of Soil and Water Conservation, Research Centre, \\ Kota- 324002 (Rajasthan), India \\ *Corresponding author
}

\begin{tabular}{|c|c|}
\hline & A B S T R A C T \\
\hline & $\begin{array}{l}\text { The present study was conducted with comprised six levels of recipe, three blending ratio, } \\
9 \text { treatments with ginger juice }(2 \%) \text { and } 9 \text { treatment without ginger juice \{aonla: lime } \\
(25: 75,50: 50 \text { and } 75: 25) \text {, aonla: orange }(25: 75,50: 50 \text { and } 75: 25) \text {, aonla: pomegranate }\end{array}$ \\
\hline Keywords & $\begin{array}{l}(25: 75,50: 50 \text { and } 75: 25) \text { with ginger juice aonla: lime: ginger }(25: 73: 2,50: 48: 2 \\
\text { and75:23:2), aonla: orange: ginger }(25: 73: 2,50: 48: 2 \text { and } 75: 23: 2) \text {, aonla: pomegranate: }\end{array}$ \\
\hline $\begin{array}{l}\text { RTS, Aonla, } \\
\text { Lime, Blended- } \\
\text { beverage, Storage. }\end{array}$ & $\begin{array}{l}\text { ginger }(25: 73: 2,50: 48: 2 \text { and } 75: 23: 2) \text { and one control }(100 \% \text { aonla juice })+\text { acidity } \\
(0.3 \%)+\text { TSS }(10 \%)\} \text {, thus total } 19 \text { treatment combination were laid out under CRD statics } \\
\text { design with three replication. Among various treatments tried in this investigation, the }\end{array}$ \\
\hline Article Info & $\begin{array}{l}\text { aonla based blended RTS beverage } T_{16} \text { treatment aonla: pomegranate: ginger }(25: 73: 2) \text { and } \\
T_{17} \text { aonla: pomegranate: ginger }(50: 48: 2) \text { were statistically at par with each other and }\end{array}$ \\
\hline $\begin{array}{l}\text { Accepted: } \\
12 \text { April } 2017 \\
\text { Available Online: } \\
10 \text { May } 2017\end{array}$ & $\begin{array}{l}\text { found best on the basis of organoleptic quality (taste, flavour and overall acceptance) after } \\
120^{\text {th }} \text { days of storage. The TSS, total sugars, reducing sugars and non-enzymatic browning } \\
\text { showed increasing trend while, the acidity, ascorbic acid, pH and phenols showed } \\
\text { decreasing trend under ambient condition. However, maximum retention of ascorbic acid }\end{array}$ \\
\hline & $\begin{array}{l}\text { was recorded in } \mathrm{T}_{17}(44.50 \mathrm{mg} / 100 \mathrm{ml}) \text { treatment and minimum acidity in } \mathrm{T}_{18}(0.34 \%) \\
\text { followed by } \mathrm{T}_{17}(0.39 \%) \text { treatment. The relative economics of treatment } \mathrm{T}_{17} \text { gave the } \\
\text { highest net return (Rs } 36.95 / \text { lit) RTS as compared to other treatments. }\end{array}$ \\
\hline
\end{tabular}

\section{Introduction}

The aonla (Emblica officinalis Gaertn) fruits are richest source of vitamin $\mathrm{C}$ being 200 to $1814 \mathrm{mg} / 100 \mathrm{~g}$ (Ram, 1990). But it has very little table value due to acrid and bitter taste. The fruits are utilized generally after processing into various products therefore, this, investigation was under taken to standardize the appropriate ratio of Aonla with lime, orange and pomegranate with and without ginger juice for preparing Aonla based blended RTS. Aonla fruit is sour and astringent in taste; hence it is not popular as table fruit and goes as a waste due to limited usage. The excellent nutritive and therapeutic value of fruits has great potentiality for processing into various quality products viz. preserve, sauce, candy, dried chips, tablets, jellies, pickles, toffees, powder, chayvanprash, etc. These products can get position in national and international markets. 
Aonla fruit juice can also be blended with other fruit juices like lime, orange, pomegranate, ginger, etc. to improve nutritional quality, taste and consumer acceptance of RTS and make use of high vitamin $\mathrm{C}$ available in Aonla fruits, processing of Aonla fruits is necessary for sustainable crop cultivation and alleviating malnutrition among rural population in addition to several health benefits. Blended RTS of Aonla with lime, orange, pomegranate and ginger for the production of new products is necessary for the survival and growth of the processing industry, to meet new taste and demand in home as well as in export market. Hence, there is an urgent need to develop some suitable technologies for the preparation of Aonla beverages which are economical and easily available to a large population. In India, soft drinks have a good demand throughout the year. Traditionally, our country has been well known for offering syrup or sharbat. If synthetic drinks can be substituted with the fruit juice, it would be beneficial to the consumers as well as fruit growers. Looking to the demand of natural beverages, there are great scopes for the preparation of juices and other fruit based beverages.

Ready-To-Serve (RTS) is a type of fruit beverage containing at least fruit juice $(10 \%)$, total soluble solids (10\%) and acidity $(0.3 \%)$ (F.P.O.1955). However, the problem encountered during processing is development of bitterness, the juices of two or more fruits are mixed to yield well balance, rightly flavoured drink, which is rich in essential minerals and vitamins. Besides, the blending of two or more juices helps in utilization of astringent and too acidic fruits like lime, sour palm, sour cherry, etc. These fruits and spice are also famous for excellent quality with pleasant flavour, rich in sugar, vitamin $\mathrm{C}$, minerals and ginger juice have antimicrobial and antibiotic properties which are good for human health. Therefore, blending of two or more fruit juices for the preparation of ready-to-serve beverage appears to be a convenient and economic alternative for utilization of Aonla. Sandhu and Sindhu (1992), Saxsena et al., (1996), Attri et al., (1998) and Langthasa (1999), have reported that two or more fruit juices/pulp may be blended in various proportions for the preparation of nectar, RTS beverage, etc.

\section{Materials and Methods}

The fully mature, Fresh and uniform fruits of Aonla were taken from the Horticulture farm of Rajasthan College of Agriculture, MPUAT, Udaipur (Raj.). There are total 19 treatment combination were laid out under Completely randomized design with three replication The immature, brownish, damaged and off type fruits were discarded and fruits of lime, orange, pomegranate and ginger were purchased from the market and brought to the Post Harvest Technology Laboratory of the Department on the same day. Fruits were inspected thoroughly for any damage and spoilage. The selected fruits were washed with tap water thoroughly to remove dirt and dust particles adhering to the surface of fruit then again washed with chlorinated water and allowed to surface dry. Their individual juice was extracted by coil type juice extractor machine, filtered through a cleaned muslin cloth and kept for few hours in refrigerator $\left(4^{0}+2^{0} \mathrm{C}\right)$ for sedimentation then after blended as per recipe treatments. Stored Aonla based blended RTS beverages was analysed for sensory (Rangana, 1978) and chemical parameters analysed as per slandered methods of (A.O.A.C, 1995) at $0,30^{\text {th }}, 60^{\text {th }}, 90^{\text {th }}$ and $120^{\text {th }}$ day of storage. The total soluble solids (TSS) measured by the "Zeiss" Hand Refractometer (0-50) and value obtained was corrected at $20^{\circ} \mathrm{C}$ (A.O.A.C, 1995). The ascorbic acid was estimated by methods suggested by (A.O.A.C, 1995), pH by digital 
$\mathrm{pH}$ meter (Systronics micro $\mathrm{pH}$ system-361) after standardization with a buffer $(\mathrm{pH} 4.0$ at $20^{\circ} \mathrm{C}$ ), non-enzymatic browning by alcohol extraction method (Klim and Nagy, 1998), phenols content was determined by Folinciocalteau phenol reagent method suggested by (Sadasivam and Manickam, 1991), total sugar content was determined by using anthrone reagents method (Dabois et al., 1951) and reducing sugar content was measured as suggested by Miller (1972) using dinitrosalicyclic acid.

\section{Results and Discussion}

Data pertaining to the effect of recipe and storage period on physico-chemical changes of aonla based blended RTS beverage (TSS, acidity, ascorbic acid, total sugar, reducing sugars, non- reducing sugars, $\mathrm{pH}$, phenols and non-enzymatic browning) during storage were studied at 15 days interval upto $120^{\text {th }}$ days.

\section{Total Soluble Solids (TSS)}

The total soluble solids content of stored aonla based blended RTS beverage increased with advancement of storage period upto the end of experimentation. The treatments found to be non-significant during entire period of storage (Table 1a). On the first day of storage the highest TSS content was observed in $\mathrm{T}_{18}$ $(10.20 \%)$ treatment, closely followed by $\mathrm{T}_{15}$ and $\mathrm{T}_{17}(10.10 \%)$. Similarly, on the $120^{\text {th }}$ day of storage the maximum TSS content was observed in $\mathrm{T}_{15}(13.00 \%)$, followed by $\mathrm{T}_{14}$ $(12.91 \%)$ whereas minimum in $\mathrm{T}_{10}(11.60 \%)$ followed by $\mathrm{T}_{8}(11.70 \%)$. The increase in total soluble solids content (on an average $10 \%$ at fresh and ) of Aonla based blended RTS beverages during storage, this might be due to hydrolysis of polysaccharides (starch), starch and pectin substances into monosaccharides (sugars) and concentration of Aonla based blended RTS beverage due to dehydration. Similar, results were observed by Godara and Pareek (1985) in date palm RTS beverage and guava beverage (Baramanray et al., 1995 and Pandey, 2004). Murtaza et al., (2004) in straw berry drink and Verma and Gehlot (2007) in bael RTS during storage.

\section{Total sugar}

A perusal of data given in table $1 \mathrm{~b}$ indicates that the total sugar content of aonla based blended RTS beverage was non-significantly influenced by recipe and storage period. On the first day of storage the highest total sugar was observed in $\mathrm{T}_{6}(9.40 \%)$ followed by $\mathrm{T}_{15}$ and $\mathrm{T}_{18}(9.39 \%)$ whereas lowest in $\mathrm{T}_{7}(7.01 \%)$ followed by $\mathrm{T}_{1}$ and $\mathrm{T}_{4}(8.30 \%)$ treatments. The total sugar content increased gradually with the increasing period of storage in all the treatments. On $120^{\text {th }}$ days of storage highest total sugar was recorded at $\mathrm{T}_{15}(12.00 \%)$ followed by $\mathrm{T}_{14} \quad(11.88 \%)$ treatment. Whereas, lowest total sugar were recorded in $\mathrm{T}_{7} \quad(10.28 \%)$ followed by $\mathrm{T}_{8} \quad(10.53 \%)$ treatment.

\section{Reducing sugar}

On the first of storage the highest reducing sugars was observed in $\mathrm{T}_{12}(7.58 \%)$ followed by $\mathrm{T}_{6}(7.52 \%)$ whereas lowest in $\mathrm{T}_{7}(5.25 \%)$ followed by $\mathrm{T}_{8}(6.26 \%)$ treatments. The reducing sugar content increased gradually with the increasing period of storage. On $120^{\text {th }}$ days of storage highest reducing sugars were recorded at $\mathrm{T}_{6}$ and $\mathrm{T}_{12} \quad(10.00 \%)$ followed by $\mathrm{T}_{19}(9.95 \%)$ treatment. Whereas, lowest reducing sugars were recorded in $\mathrm{T}_{7}$ $(8.00 \%)$ followed by $\mathrm{T}_{8}(8.42 \%)$ treatment. However, treatments $\mathrm{T}_{2}, \mathrm{~T}_{3}, \mathrm{~T}_{5}, \mathrm{~T}_{6}, \mathrm{~T}_{12}, \mathrm{~T}_{14}$, $\mathrm{T}_{15}, \mathrm{~T}_{16}, \mathrm{~T}_{17}, \mathrm{~T}_{18}$ and $\mathrm{T}_{19}$ were found statistically at par with each other (Table 2a). The total sugar content of Aonla based blended RTS beverages increased during storage period. This could be attributed to the fact that, the hydrolysis of polysaccharides during storage results an increase in soluble sugars. 
Table.1 Effect of recipe treatments on (A) total soluble solids and (B) total sugar content of Aonla based blended RTS beverages during storage

\begin{tabular}{|c|c|c|c|c|c|c|c|c|c|c|c|}
\hline \multirow{3}{*}{ S.N. } & \multirow{3}{*}{ Treatments } & \multicolumn{5}{|c|}{ (A) Total soluble solids (\%) } & \multicolumn{5}{|c|}{ (B) Total sugar (\%) } \\
\hline & & \multicolumn{5}{|c|}{ Storage Period (Days) } & \multicolumn{5}{|c|}{ Storage Period (Days) } \\
\hline & & $\mathbf{0}$ & 30 & 60 & 90 & 120 & $\mathbf{0}$ & 30 & 60 & 90 & 120 \\
\hline 1. & Aonla: Lime (25:75) & 10.00 & 10.32 & 11.00 & 11.50 & 11.90 & 0.76 & 0.40 & 0.42 & 0.57 & 0.75 \\
\hline 2. & Aonla: Lime (50:50) & 10.00 & 10.35 & 11.15 & 11.90 & 12.30 & 2.09 & 1.91 & 1.32 & 1.86 & 2.00 \\
\hline 3. & Aonla: Lime $(75: 25)$ & 10.00 & 10.45 & 11.16 & 12.00 & 12.40 & 1.40 & 1.22 & 0.72 & 0.82 & 1.06 \\
\hline 4. & Aonla: Orange (25:75) & 10.00 & 10.16 & 10.83 & 11.45 & 12.10 & 1.19 & 0.99 & 0.52 & 0.75 & 1.13 \\
\hline 5. & Aonla: Orange (50:50) & 10.00 & 10.11 & 10.80 & 11.42 & 12.20 & 1.25 & 1.05 & 0.53 & 0.82 & 1.13 \\
\hline 6. & Aonla: Orange $(75: 25)$ & 10.00 & 10.20 & 10.90 & 11.69 & 12.50 & 3.17 & 2.89 & 2.55 & 2.81 & 2.90 \\
\hline 7. & Aonla: Pomegranate (25:75) & 10.00 & 10.45 & 11.00 & 11.75 & 12.30 & 1.98 & 1.62 & 1.21 & 1.43 & 1.50 \\
\hline 8. & Aonla: Pomegranate (50:50) & 10.00 & 10.29 & 11.00 & 11.17 & 11.70 & 1.00 & 0.82 & 0.55 & 0.73 & 0.85 \\
\hline 9. & Aonla: Pomegranate $(75: 25)$ & 10.00 & 10.32 & 11.02 & 11.46 & 12.10 & 0.97 & 0.72 & 0.67 & 0.86 & 0.92 \\
\hline 10. & Aonla: Lime: Ginger (25:73:2) & 10.00 & 10.19 & 10.45 & 11.00 & 11.60 & 1.10 & 0.81 & 0.58 & 0.78 & 0.99 \\
\hline 11. & Aonla: Lime: Ginger (50:48:2) & 10.00 & 10.21 & 10.85 & 11.35 & 12.00 & 2.01 & 1.80 & 1.41 & 0.67 & 1.86 \\
\hline 12. & Aonla: Lime: Ginger $(75: 23: 2)$ & 10.00 & 10.24 & 10.90 & 11.48 & 12.10 & 0.99 & 0.75 & 0.49 & 0.75 & 0.91 \\
\hline 13. & Aonla: Orange: Ginger (25:73:2) & 10.00 & 10.26 & 11.05 & 11.71 & 12.30 & 1.01 & 0.85 & 0.51 & 0.72 & 0.81 \\
\hline 14. & Aonla: Orange: Ginger (50:48:2) & 10.00 & 10.26 & 11.03 & 11.71 & 12.91 & 1.26 & 0.96 & 0.61 & 0.84 & 0.99 \\
\hline 15. & Aonla: Orange: Ginger $(75: 23: 2)$ & 10.00 & 10.48 & 11.17 & 11.86 & 13.00 & 1.06 & 0.86 & 0.64 & 0.88 & 0.98 \\
\hline 16. & Aonla: Pomegranate: Ginger $(25: 73: 2)$ & 10.00 & 10.45 & 10.89 & 11.45 & 12.20 & 1.00 & 0.82 & 0.51 & 0.60 & 0.80 \\
\hline 17. & Aonla: Pomegranate: Ginger (50:48:2) & 10.00 & 10.57 & 11.09 & 11.60 & 12.50 & 1.29 & 0.96 & 0.75 & 0.89 & 1.07 \\
\hline 18. & Aonla: Pomegranate: Ginger $(75: 23: 2)$ & 10.00 & 10.68 & 11.28 & 12.00 & 12.90 & 1.49 & 0.99 & 0.75 & 0.94 & 1.09 \\
\hline 19. & Control(100\% Aonla juice) & 10.00 & 10.45 & 11.20 & 11.90 & 12.80 & 1.60 & 1.03 & 0.80 & 0.98 & 1.22 \\
\hline \multicolumn{2}{|c|}{$\mathrm{SEm} \pm$} & 0.24 & 0.25 & 0.27 & 0.28 & 0.30 & 0.037 & 0.030 & 0.022 & 0.021 & 0.031 \\
\hline \multicolumn{2}{|c|}{$\mathrm{CD}(\mathrm{P}=0.01)$} & NS & $\mathrm{NS}$ & NS & NS & NS & 0.140 & 0.114 & $\mathrm{NS}$ & NS & NS \\
\hline
\end{tabular}


Table.2 Effect of recipe treatments on (A) Reducing sugar and (B) Ascorbic acid content of Aonla based blended RTS beverages during storage

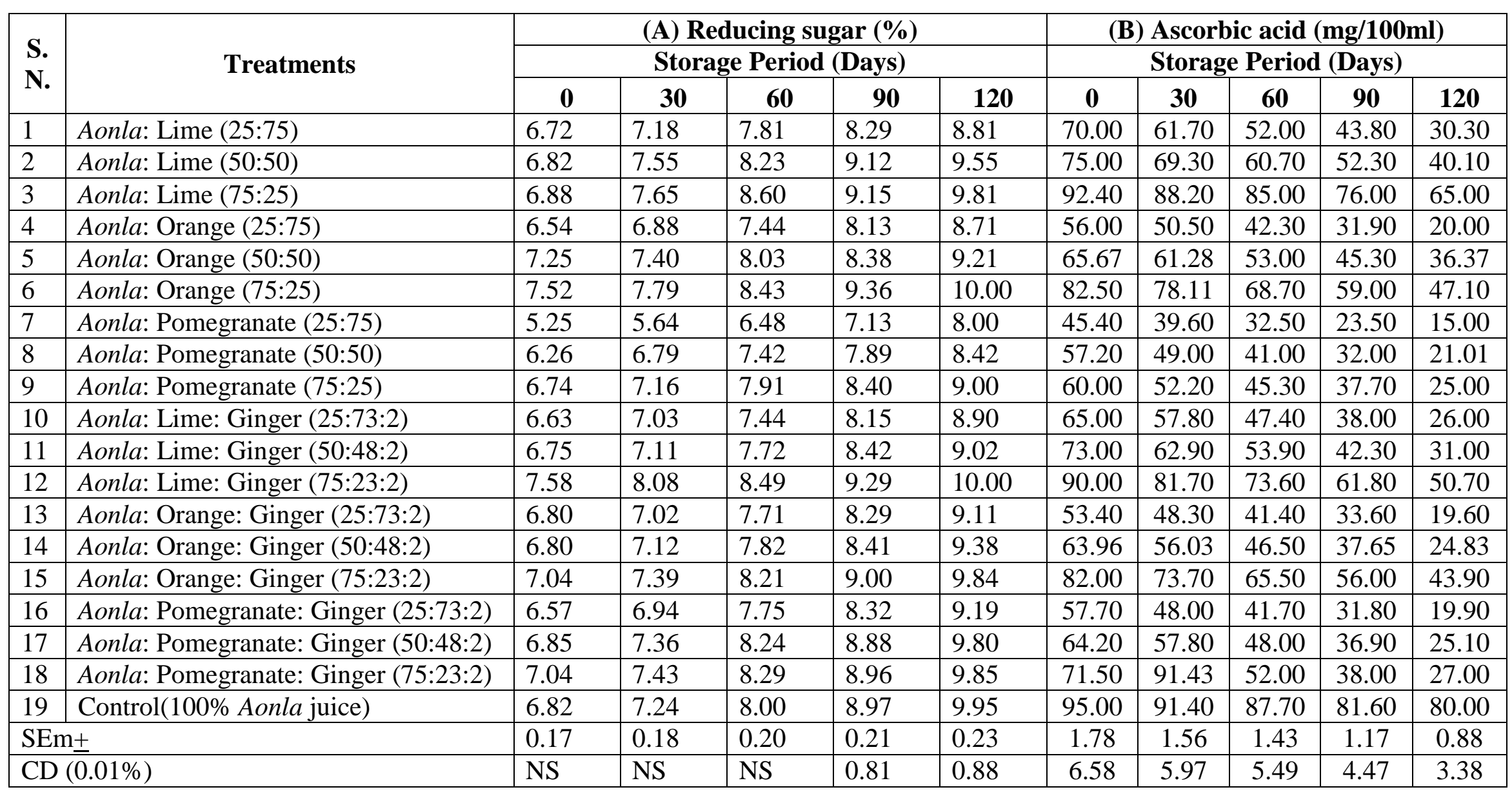


Table.3 Effect of recipe treatments on (A) pH (B) phenol of Aonla based blended RTS beverages during storage

\begin{tabular}{|c|c|c|c|c|c|c|c|c|c|c|c|}
\hline \multirow{3}{*}{ S.N. } & \multirow{3}{*}{ Treatments } & \multicolumn{5}{|c|}{ (A) pH } & \multicolumn{5}{|c|}{ (B) Phenol (\%) } \\
\hline & & \multicolumn{5}{|c|}{ Storage Period (Days) } & \multicolumn{5}{|c|}{ Storage Period (Days) } \\
\hline & & $\mathbf{0}$ & 30 & 60 & 90 & 120 & $\mathbf{0}$ & 30 & 60 & 90 & 120 \\
\hline 1. & Aonla: Lime (25:75) & 2.73 & 2.69 & 2.58 & 2.49 & 2.44 & 0.76 & 0.40 & 0.42 & 0.57 & 0.75 \\
\hline 2. & Aonla: Lime (50:50) & 2.72 & 2.70 & 2.62 & 2.52 & 2.47 & 2.09 & 1.91 & 1.32 & 1.86 & 2.00 \\
\hline 3. & Aonla: Lime $(75: 25)$ & 2.84 & 2.81 & 2.73 & 2.68 & 2.54 & 1.40 & 1.22 & 0.72 & 0.82 & 1.06 \\
\hline 4. & Aonla: Orange $(25: 75)$ & 3.00 & 2.96 & 2.92 & 2.88 & 2.82 & 1.19 & 0.99 & 0.52 & 0.75 & 1.13 \\
\hline 5. & Aonla: Orange (50:50) & 2.93 & 2.91 & 2.90 & 2.80 & 2.65 & 1.25 & 1.05 & 0.53 & 0.82 & 1.13 \\
\hline 6. & Aonla: Orange $(75: 25)$ & 2.96 & 2.91 & 2.87 & 2.80 & 2.68 & 3.17 & 2.89 & 2.55 & 2.81 & 2.90 \\
\hline 7. & Aonla: Pomegranate $(25: 75)$ & 2.77 & 2.75 & 2.71 & 2.69 & 2.68 & 1.98 & 1.62 & 1.21 & 1.43 & 1.50 \\
\hline 8. & Aonla: Pomegranate $(50: 50)$ & 2.58 & 2.55 & 2.53 & 2.50 & 2.48 & 1.00 & 0.82 & 0.55 & 0.73 & 0.85 \\
\hline 9. & Aonla: Pomegranate $(75: 25)$ & 2.66 & 2.64 & 2.59 & 2.57 & 2.55 & 0.97 & 0.72 & 0.67 & 0.86 & 0.92 \\
\hline 10. & Aonla: Lime: Ginger $(25: 73: 2)$ & 2.59 & 2.55 & 2.47 & 2.41 & 2.36 & 1.10 & 0.81 & 0.58 & 0.78 & 0.99 \\
\hline 11. & Aonla: Lime: Ginger (50:48:2) & 2.79 & 2.76 & 2.71 & 2.70 & 2.68 & 2.01 & 1.80 & 1.41 & 0.67 & 1.86 \\
\hline 12. & Aonla: Lime: Ginger $(75: 23: 2)$ & 2.93 & 2.90 & 2.84 & 2.80 & 2.78 & 0.99 & 0.75 & 0.49 & 0.75 & 0.91 \\
\hline 13. & Aonla: Orange: Ginger (25:73:2) & 2.98 & 2.91 & 2.87 & 2.81 & 2.78 & 1.01 & 0.85 & 0.51 & 0.72 & 0.81 \\
\hline 14. & Aonla: Orange: Ginger (50:48:2) & 2.86 & 2.85 & 2.78 & 2.68 & 2.58 & 1.26 & 0.96 & 0.61 & 0.84 & 0.99 \\
\hline 15. & Aonla: Orange: Ginger $(75: 23: 2)$ & 2.85 & 2.81 & 2.78 & 2.69 & 2.61 & 1.06 & 0.86 & 0.64 & 0.88 & 0.98 \\
\hline 16. & Aonla: Pomegranate: Ginger (25:73:2) & 2.72 & 2.70 & 2.64 & 2.57 & 2.46 & 1.00 & 0.82 & 0.51 & 0.60 & 0.80 \\
\hline 17. & Aonla: Pomegranate: Ginger $(50: 48: 2)$ & 2.74 & 2.70 & 2.63 & 2.58 & 2.56 & 1.29 & 0.96 & 0.75 & 0.89 & 1.07 \\
\hline 18. & Aonla: Pomegranate: Ginger $(75: 23: 2)$ & 2.78 & 2.76 & 2.74 & 2.70 & 2.68 & 1.49 & 0.99 & 0.75 & 0.94 & 1.09 \\
\hline 19. & Control(100\% Aonla juice) & 3.03 & 2.79 & 2.70 & 2.63 & 2.60 & 1.60 & 1.03 & 0.80 & 0.98 & 1.22 \\
\hline \multicolumn{2}{|c|}{$\mathrm{SEm} \pm$} & 0.061 & 0.057 & 0.063 & 0.057 & 0.058 & 0.037 & 0.030 & 0.022 & 0.021 & 0.031 \\
\hline \multicolumn{2}{|c|}{$\mathrm{CD}(\mathrm{P}=0.01)$} & 0.324 & NS & NS & NS & NS & 0.140 & 0.114 & NS & NS & $\mathrm{NS}$ \\
\hline
\end{tabular}


Table.4 Effect of recipe treatments on (A) non-enzymatic browning (OD) and (B) Overall organoleptic score of Aonla based blended RTS beverages during storage

\begin{tabular}{|c|c|c|c|c|c|c|c|c|c|c|c|}
\hline \multirow{3}{*}{$\begin{array}{l}\text { S. } \\
\text { N. }\end{array}$} & \multirow{3}{*}{ Treatments } & \multirow{2}{*}{\multicolumn{5}{|c|}{$\frac{\text { (A) Non-enzymatic browning }}{\text { Storage Period (Days) }}$}} & \multicolumn{5}{|c|}{ (B) Overall organoleptic score } \\
\hline & & & & & & & \multicolumn{5}{|c|}{ Storage Period (Days) } \\
\hline & & $\mathbf{0}$ & 30 & 60 & 90 & 120 & $\mathbf{0}$ & 30 & 60 & 90 & 120 \\
\hline 1 & Aonla: Lime (25:75) & 0.018 & 0.018 & 0.041 & 0.068 & 0.100 & 8.17 & 7.82 & 7.23 & 6.36 & 5.48 \\
\hline 2 & Aonla: Lime (50:50) & 0.023 & 0.026 & 0.080 & 0.092 & 0.110 & 8.15 & 7.72 & 7.06 & 7.71 & 5.41 \\
\hline 3 & Aonla: Lime $(75: 25)$ & 0.025 & 0.039 & 0.093 & 0.150 & 0.180 & 8.00 & 7.46 & 6.82 & 6.09 & 5.29 \\
\hline 4 & Aonla: Orange (25:75) & 0.027 & 0.033 & 0.058 & 0.080 & 0.094 & 8.18 & 7.87 & 7.31 & 6.71 & 5.60 \\
\hline 5 & Aonla: Orange (50:50) & 0.032 & 0.034 & 0.083 & 0.105 & 0.115 & 8.09 & 7.67 & 7.10 & 6.36 & 5.39 \\
\hline 6 & Aonla: Orange $(75: 25)$ & 0.037 & 0.058 & 0.092 & 0.135 & 0.152 & 8.03 & 7.50 & 7.09 & 6.27 & 5.31 \\
\hline 7 & Aonla: Pomegranate (25:75) & 0.035 & 0.035 & 0.067 & 0.082 & 0.108 & 8.25 & 7.89 & 7.33 & 6.75 & 5.90 \\
\hline 8 & Aonla: Pomegranate (50:50) & 0.041 & 0.047 & 0.086 & 0.110 & 0.134 & 8.19 & 7.76 & 7.24 & 6.66 & 5.79 \\
\hline 9 & Aonla: Pomegranate (75:25) & 0.047 & 0.068 & 0.093 & 0.138 & 0.144 & 8.14 & 7.68 & 7.10 & 6.43 & 5.72 \\
\hline 10 & Aonla: Lime: Ginger (25:73:2) & 0.020 & 0.020 & 0.057 & 0.076 & 0.105 & 8.58 & 8.18 & 7.62 & 7.27 & 6.92 \\
\hline 11 & Aonla: Lime: Ginger (50:48:2) & 0.024 & 0.035 & 0.066 & 0.076 & 0.109 & 8.45 & 8.07 & 7.48 & 7.04 & 6.80 \\
\hline 12 & Aonla: Lime: Ginger $(75: 23: 2)$ & 0.024 & 0.041 & 0.069 & 0.085 & 0.118 & 8.41 & 8.05 & 7.37 & 6.95 & 6.60 \\
\hline 13 & Aonla: Orange: Ginger (25:73:2) & 0.023 & 0.034 & 0.061 & 0.070 & 0.106 & 8.46 & 8.16 & 7.91 & 7.30 & 6.84 \\
\hline 14 & Aonla: Orange: Ginger (50:48:2) & 0.035 & 0.041 & 0.067 & 0.081 & 0.110 & 8.36 & 8.06 & 7.82 & 7.16 & 6.76 \\
\hline 15 & Aonla: Orange: Ginger $(75: 23: 2)$ & 0.047 & 0.047 & 0.082 & 0.085 & 0.120 & 8.27 & 8.00 & 7.75 & 7.07 & 6.70 \\
\hline 16 & $\begin{array}{l}\text { Aonla: Pomegranate: Ginger } \\
(25: 73: 2)\end{array}$ & 0.041 & 0.044 & 0.076 & 0.084 & 0.118 & 9.00 & 8.85 & 8.70 & 8.57 & 8.13 \\
\hline 17 & $\begin{array}{l}\text { Aonla: Pomegranate: Ginger } \\
(50: 48: 2)\end{array}$ & 0.045 & 0.050 & 0.085 & 0.106 & 0.125 & 8.88 & 8.61 & 8.17 & 7.97 & 7.75 \\
\hline 18 & $\begin{array}{l}\text { Aonla: Pomegranate: Ginger } \\
(75: 23: 2)\end{array}$ & 0.048 & 0.057 & 0.099 & 0.127 & 0.134 & 8.58 & 8.35 & 8.15 & 7.79 & 7.37 \\
\hline 19 & Control(100\% Aonla juice) & 0.033 & 0.041 & 0.076 & 0.101 & 0.125 & 6.66 & 6.29 & 5.75 & 4.97 & 4.05 \\
\hline $\mathrm{SEI}$ & & 0.0008 & 0.0012 & 0.0018 & 0.0022 & 0.0027 & 0.20 & 0.19 & 0.17 & 0.16 & 0.15 \\
\hline $\mathrm{CD}$ & $(0.01 \%)$ & NS & NS & NS & NS & NS & NS & NS & NS & NS & NS \\
\hline
\end{tabular}


Total sugars of beverages were depended on the total soluble solids as anticipated. There was considerable rise in reducing sugars and nonreducing sugars. This might be due to inversion on non-reducing sugars to reducing sugars caused by acids present in of Aonla based blended RTS beverages. Increase in total and reducing sugars during storage is a general phenomenon as noticed by Ray and Singh (1979) in bael beverages, Godara and Pareek (1985) in date palm RTS beverage at room temperature $\left(25 \pm 5^{0} \mathrm{C}\right)$ Verma and Gehlot (2007) in bael RTS.

\section{Ascorbic acid}

The ascorbic acid content of aonla based blended RTS beverage decreased with advancement of storage period in all the treatments. The treatments had significant effect on ascorbic acid content of aonla based blended RTS beverage during the entire storage period (Table 2b). On the first day of storage the maximum ascorbic acid content was observed in $\mathrm{T}_{19}(95.00 \mathrm{mg} / 100 \mathrm{ml})$ and minimum in $\mathrm{T}_{7}$ $(45.40 \mathrm{mg} / 100 \mathrm{ml})$, however treatment $\mathrm{T}_{3}, \mathrm{~T}_{12}$ and $\mathrm{T}_{19}$ were found statistically at par with each other. Similarly, on $120^{\text {th }}$ day of storage, the maximum ascorbic acid content was observed at $\mathrm{T}_{19}(80.00 \mathrm{mg} / 100 \mathrm{ml})$, followed by $\mathrm{T}_{3}$ $(65.00 \mathrm{mg} / 100 \mathrm{ml})$ treatment whereas minimum in $\mathrm{T}_{7}(15.00 \mathrm{mg} / 100 \mathrm{ml})$, followed by $\mathrm{T}_{13}$ $(19.60 \mathrm{mg} / 100 \mathrm{ml})$. A gradual and significant decrease in ascorbic acid content with the increasing period of storage was observed in all the treatments. The maximum retention of ascorbic acid was observed in $\mathrm{T}_{17}$ $(44.50 \mathrm{mg} / 100 \mathrm{ml})$ and minimum in $\mathrm{T}_{19}$ $(25.00 \mathrm{mg} / 100 \mathrm{ml})$ treatment. The trend observed same throughout the storage period. Ascorbic acid content reduced considerably during storage period might be due to the oxidation or irreversible conversion of L-ascorbic acid into dihydro ascorbic acid oxidase (ascorbinase) because of heat processing and the presence of air at the head space of glass bottles. Similar, trend of declining was noticed by Palainswamy and Muthukrishnan (1974) in lemon juice during storage varied between 21.76 to 62.06 mg/100ml juice. Ray and Singh (1979) in bael beverages and by Reddy and Chikkasubbanna (2008) in lime blended amla squash during storage period of 90 days.

\section{pH value}

The pH content of aonla based blended RTS beverage decreased with advancement of storage period in all the treatments. The treatments have a non-significant effect on $\mathrm{pH}$ content of aonla based blended RTS beverage during entire storage periods except on the 15 days of storage (Table 3a). On the first day of storage the maximum $\mathrm{pH}$ content was observed in $\mathrm{T}_{19}$ (3.03) treatment, closely followed by $\mathrm{T}_{4}$ (3.00), whereas minimum in $\mathrm{T}_{8}$ (2.58). Similarly, at the end of storage period the maximum $\mathrm{pH}$ content was observed in $\mathrm{T}_{4}(2.82)$ and minimum in $\mathrm{T}_{10}$ (2.36). The $\mathrm{pH}$ of Aonla based blended RTS beverage decreased with the increased period of storage. A corresponding decrease in acidity due to chemical reaction taking place between organic acids and pigments could be responsible for change in $\mathrm{pH}$ (Kannan and Thirumaran, 2004). Similar observations were reported by Krishnaveni et al., (2001) in jackfruit RTS beverage during storage at room temperature. Murtaza et al., (2004) in strawberry drinks at ambient temperature $\left(25^{\circ} \mathrm{C}\right)$. An increasing trend in $\mathrm{pH}$ of lime-Aonla blended squash during storage period of 90 days has also been reported by Reddy and Chikkasubbanna (2008).

\section{Phenols}

The maximum phenols contents on first day of storage was recorded at $\mathrm{T}_{6}(3.17 \%)$, followed by $\mathrm{T}_{2}(2.09 \%)$, which continued to be maximum till the end of storage period $(2.90 \%)$ and $(2.00 \%)$ respectively. While minimum phenol content were observed in $\mathrm{T}_{1}(0.76 \%)$ followed by $\mathrm{T}_{9}(0.97 \%)$. The minimum phenolic content at $120^{\text {th }}$ days of storage was recorded in treatment $\mathrm{T}_{1}(0.75 \%)$ followed by $\mathrm{T}_{16}$ $(0.80 \%)$.The Phenols contents of Aonla based blended RTS beverage decrease slightly during storage period (Table $3 \mathrm{~b}$ ). Initial content of 
phenols in RTS compaired at end of storage period was less, which may be due to thermal degradation during pasteurization and processing. The decrease in phenols content might also be due to increased activity of polyphenol oxidase (PPO) enzyme activity. Poonam and Tandon (2007) obtained similar results in guava-Aonla blended beverage. Verma and Gehlot (2007) in bael RTS beverage during storage, Reddy and Chikkasubbanna (2008) in lime-Aonla blended squash.

\section{Non-enzymatic browning}

The non-enzymatic browning content of aonla based blended RTS beverage non-significantly affected by the recipe and storage period of aonla based RTS beverage during storage period except on $45^{\text {th }}, 75^{\text {th }}$ and $105^{\text {th }}$ days of storage (Table 4a) and increased with the advancement of storage. On the first day of storage the non-enzymatic browning found to be highest in $\mathrm{T}_{18}(0.048 \mathrm{OD})$, followed by $\mathrm{T}_{9}$ and $\mathrm{T}_{15}(0.047 \mathrm{OD})$ treatments whereas, the least in $\mathrm{T}_{1}(0.018 \mathrm{OD})$ followed by $\mathrm{T}_{10}(0.020$ OD). Similarly, on the $120^{\text {th }}$ days of storage the maximum non-enzymatic browning contents observed in $\mathrm{T}_{3}\left(0.180\right.$ OD) followed by $\mathrm{T}_{6}$ $\left(0.152\right.$ OD) treatment, whereas minimum in $\mathrm{T}_{4}$ (0.94 OD). A gradual increase in non-enzymatic browning in Aonla based blended RTS beverage with increase in storage period at room temperature might be due to enzymatic and non-enzymatic reactions in RTS. The possibility of browning due to enzymes is ruled out because at such high temperature, enzymes get inactivated. Therefore, browning has taken place through the non-enzymatic reactions and oxidation of various phenolics and other compounds which lead to the formation of brown pigment. Similar, results were observed by Brekke et al., (1970) in guava concentrates 2 months of storage. Khurdiya and Anand (1981) in phalsa beverages and by Poonma and Tondan (2007) in the guava-Aonla blended beverages increased with prolongation of storage period.

\section{Overall acceptance}

It is clear from the data that the overall acceptance of aonla based RTS beverage was decreased as the storage period increased in all the treatments. However, on the $120^{\text {th }}$ the highest overall acceptance value (8.13) was obtained at $\mathrm{T}_{16}$ followed by $\mathrm{T}_{17}$ (7.97) treatment which, were significantly higher than the other treatments (Table 4b). The lowest value (4.05) was recorded at $\mathrm{T}_{19}$ (control) treatment. On the 120 days of storage treatments $T_{16}$ and $T_{17}$ were found statistically at par with each other. Overall acceptance of Aonla based blended RTS beverages was influenced by recipe and treatment combination revealed that it decreased as the storage period increased. On $120^{\text {th }}$ day of storage the maximum overall acceptance score decreased from 9.00 to $8.13\left(\mathrm{~T}_{16}\right)$ followed by $\mathrm{T}_{17}$ (8.88). The colour, taste and flavour are important consideration for overall acceptance of Aonla RTS beverage. The present findings are in accordance with findings reported by Khurdiya and Anand (1981) in phalsa and Jain et al., (1984) in lemon, orange and bael fruit squashes. Similarly, Pandey (2004) in guava RTS beverage and squash gradually decreased at ambient temperature for 5 months. Kotcha and Kadam (2003) in RTS, syrup and concentrate of tamarind, Poonam and Tondan (2007) observed that as the concentration of Aonla pulp increased their acceptability decreased in guava-Aonla blended beverage.

\section{References}

A.O.A.C. 1995. Official method of analysis of Association of official Analytical chemist, Washington, D.C., 16-37.

Attri, B.L., Lal, B.B. and Joshi, V.K. 1998. Physico-chemical characteristics, sensory quality and storage behaviour of sand pear juice blended with temperate fruit juices/pulp. Indian Food Packer, 52(6): 3642.

Baramanray, A., Gupta, O.P and Dhawan, S.S. 1995. Evaluation of guava (Psidium guajava L.) hybrids for making nectar. Haryana J. Hortic. Sci, 24(2):102-109.

Brekke, J.E., Tonaki, K.I., Caoalaetto, C.G. and Frank, H.A. 1970. Stability of guava puree concentrates during refrigerated storage, $J$. 
Food Sci., 35(4): 469-471.

Dabois, M., Gilles, K., Hamilton, J.K., Robbers, P.A. and Smith, F. 1951. A colorimetric method for determination of sugar. Nature, 16: 167.

F.P.O. 1955. The Food Products Order. Central Govt. commodities Act.

Godara, R.K. and Pareek, O.P. 1985. Effect of temperature on Storage life of ready-toserve date palm beverage. Indian J. Agri. Sci., 55(5): 347-349.

Kannan, S. and Thrumaran, A.S. 2004. Studies on the storage life of jamun fruit products. $J$. Food Sci. Technol., 41: 186-188.

Klim, M. and Negy, S. 1998. An improved method to determine non-enzymatic browning in citrus juices. J. Agri. Food Chem., 36(6): 1271-1274.

Kotecha, P.M. and Kadam, S.S. 2003. Preparation of ready-to-serve beverage, syrup and concentrate from tamarind. J. Food Sci. Technol., Mysore, 40(1): 76-79.

Krishnaveni, A., Maninegalai, G. and Saravankumar. 2001. Storage stability of jackfruit (Atrocarpus hetrophyllus) RTS beverage. J. Food Sci. Technol., Maysore, 38: 601-602.

Langthasa, S. 1999. Processing and preservation of apple pulp. Ph.D. Thesis. I.A.R.I. New Delhi.

Miller, G.L. 1972. Determination of reducing sugars using 3, 5-dinitrosalicyclic acid. Anal. Chem., 31(3): 459.

Murtaza, M.A., Nuzhat, Huma., Juanid, Javaid., Shabbor, M.A., Din, G.M.U. and Shahid Mohamood. 2004. Studies on stability of Strawberry drink stored at different temperatures. Int. J. Agri. Biol., 6(1): 58-60.

Murtaza, M.A., Nuzhat, Huma., Juanid, Javaid., Shabbor, M.A., Din, G.M.U. and Shahid Mohamood. 2004. Studies on stability of Strawberry drink stored at different temperatures. Int. J. Agri. Biol., 6(1): 58-60.
Palainswamy, K.P. and Muthukrishanan, C.R. 1974. Studies the physico-chemical characters of lemon juice squashes during storage. Indian Food Packer, 28(4): 37-41.

Pandey, A.K. 2004. Study about the storage Stability of guava beverages. Progressive Horticulture, 36(1): 142-145.

Poonam, Mall. and Tandon, D.K. 2007. Development of guava-Aonla blended beverage. Acta Horticulture, 735: 555-560.

Ram, S.1990. Amla cultivation. Indian Farm Digest, 22: 9-12.

Rangana, S. 1978. Hand book of analysis and quality control for fruit and vegetable products. Tata Mc Grow Hill Publishing Co. Ltd. New Delhi.

Ray, S.K. and Singh, R.N.1979. Studies on utilization of bael fruit (Aegle marmelos Correa) from processing. Storage studies on bael products. Indian Food Packer, 33(6): 3-9.

Reddy, A., Harshvardhan and Chikkasubbanna, V. 2008. Standardization of recipe and storage behaviour of lime blended amla squash. The Asian J. Horticulture, 2: 203-207.

Sadasivam, S. and Manickam, A. 1991. Biochemical Methods for Agriculture Sci., Wiley Eastern Limited, New Delhi, Pp: 187-195.

Sandhu, K.S. and Sindhu, J.S. 1992. Studies on the development of multi fruits ready- toserve beverages. J. Plant Sci. Res., 8: 8788.

Saxsena, A.K., Teotia, M.S. and Berry, S.K. 1996. Studies on the development grape-mango and grape-pineapple beverage blends. Indian Food Packer, 50: 26-29.

Verma, S. and Gehlot, R. 2007. Studies on development and evolutions of ready-toserve (RTS) drink from bael (Aegle marmelos Correa). Res. Crops, 8(3): 745748.

\section{How to cite this article:}

Naval Singh Devra, R.A. Kaushik and H.R. Meena. 2017. Standardization and Storage Study of Aonla (Emblica officinalis Gaertn) based Blended Ready-To-Serve Beverages. Int.J.Curr.Microbiol.App.Sci. 6(5): 1275-1284. doi: https://doi.org/10.20546/ijcmas.2017.605.138 